\title{
Accounting and evaluation of chemical footprint of cotton woven fabrics
}

\author{
DOI: 10.35530/IT.071.03.1678
}

JIA-HONG QIAN

\section{ABSTRACT - REZUMAT}

\section{Accounting and evaluation of chemical footprint of cotton woven fabrics}

The major environmental impacts of textile products tend to arise from emissions of toxic substances in the production phase of the life cycle. The theory of chemical footprint (ChF) can be used to study the environmental impact of textile products and leads a new way to quantitatively assess impacts of toxic substances. In this paper, environmental impacts of $1 \mathrm{~kg}$ cotton woven fabric were assessed from yarn to finished fabric in terms of its contributions to the ecological system. The results showed that the total ChF in the calculation boundary associated with ecotoxicity was approximately $41526.10 \mathrm{PAF} \cdot \mathrm{m}^{3} \cdot d$. The largest ChF for cotton woven fabric mainly came from weaving process, followed by cultivation and harvesting and fabric processing phases. Sizing agent and all kinds of base potentially created the large ecotoxicity and there are considerable differences in magnitude from other materials' ecotoxicity. It also revealed that the selection of auxiliaries was more important than that of dyestuffs. ChF does well in drawing more focus on the source of industry pollution and plays an important role in improving management efficiency in assessing and choosing chemicals.

Keywords: chemical footprint, environmental load, cotton woven fabrics, productive technologies

\section{Evidența și evaluarea amprentei chimice a țesăturilor din bumbac}

Impactul major asupra mediului al produselor textile apare din emisiile de substanțe toxice în faza de producție a ciclului de viață. Teoria amprentei chimice (ChF) poate fi utilizată pentru a studia impactul asupra mediului al produselor textile și conduce la o nouă modalitate de evaluare cantitativă a impactului substanțelor toxice. În această lucrare, impactul asupra mediului al țesăturii din bumbac de $1 \mathrm{~kg}$ a fost evaluat de la fire până la țesăturile finite, din punctul de vedere al contribuțiilor la sistemul ecologic. Rezultatele au arătat că ChF total în limita de calcul asociată cu ecotoxicitatea a fost de aproximativ de 41526,10 $\mathrm{PAF} \cdot \mathrm{m}^{3} \cdot d$. Cea mai mare valoare ChF pentru țesătura din bumbac a provenit în principal din procesul de țesere, urmat de cultivare și recoltare și fazele de prelucrare ale țesăturilor. Agentul de încleiere a creat o posibilă ecotoxicitate ridicată și există diferențe considerabile de ecotoxicitate față de alte materiale. De asemenea, s-a constatat că selecția substanțelor auxiliare a fost mai importantă decât cea a coloranților. ChF identifică sursa de poluare din industrie și deține un rol important în managementul eficient de evaluarea și selecție al substanțelor chimice.

Cuvinte-cheie: amprenta chimică, protecția mediului, țesături din bumbac, tehnologii de producție

\section{INTRODUCTION}

Chemicals play a crucial role in providing function for materials and products among other things. The textile industry, one of the world's largest industries, is an intense user of chemicals. Currently, millions of chemicals are consumed in the manufacturing of textiles products. A study showed that between 1.5 to $6.9 \mathrm{~kg}$ of chemicals are used per kg textiles, which means that the weight of chemicals used in the production process is larger than that of the finished garment [1]. Not only will chemical pollution influence economic development [2], but also they can reach environmental compartments and do damage to human health and ecological environment.

Commonly, chemicals tend to be released in the form of mixture. As a result, it is almost impossible to know the potential impact that all these chemical compounds and their mixtures might generate, unless a large amount of money, resources and time are spent [3].
The theory of chemical footprint (ChF) provides a new idea for environmental load assessment that recommends people to keep a watchful eye on the chemicals' toxicity in the production and makes it possible for civil society and companies to be the important subject in regulating pollution as a quantitative evaluation tool [4]. The idea of ChF was first introduced in a commercial report in 2011 [5] and has gained extensive interest since then. The ChF research is still in its early stages. In summary, the concepts of ChF can be grouped into three categories: toxic stress, environmental space or mass of chemicals and the first explanation is considered more reasonable in product level [1]. It means that it is a method characterized by the potential human toxicity and ecological toxicity of chemical pollutants discharged by human activities. ChF tends to be estimated by using the existing mature models in the field of ecotoxicology and USEtox model is the consensus model resulting from extensive comparison of existing Life Cycle Assessment (LCA) methods for 
toxicity impact assessment by an international team of LCA experts [6]. For example, Sala and Goralczyk [7] used the concept of comparative toxic unit for freshwater ecosystem in that model to characterize the ecological toxic effects of chemicals in European Union. In 2014, combining with the weight of chemical emission, Bjørn et al. [8] gave the chemical footprint calculation formula and calculated the region scale ChF. Roos et al. [9] firstly introduced USEtox model into textile and apparel industry, and concluded that the unbleached garments were not better than bleached ones when taking the service life into account.

Cotton textiles are one of the most important products for good performance, such as durability, easy washability and comfort. According to statistics, the global cotton fiber output in 2016 was 23.21 million tons, accounting for nearly a quarter of the total fiber output [10]. In the production of cotton textiles, wet treatment, including pre-treatment, mercerizing, dyeing and finishing, is considered as an infamous source of the environmental load, in which abundant chemicals, water resources and energy will be consumed [11]. Attention has increasingly been paid to the environmental problems in the production of cotton textiles, and climate change and water use are well-developed impact categories in assessing environmental load [12]. Both semi-finished products and finished products like cotton woven bags [13], T-shirts [14], fabrics [15-16], yarns [17] and fibres [18] have been studied, aiming at evaluating the greenhouse gases, water shortage or other categories in their life cycle. However, there is negligible literature published on the impacts of toxicity on the environment that brought about by chemical use in cotton textile production based on chemical footprint theory, though the effects of chemicals are more profound and lasting.

Therefore, this study is aimed at assessing and comparing the potential ecotoxicity impacts of different processes in cotton woven fabric production by accounting $\mathrm{ChF}$, and raising public attention on the use and election of textile chemicals. The main part of the article includes the following aspects: the first part is methodology and data, the second is results and discussion, and the last is conclusion.

\section{METHODOLOGY AND DATA}

\section{Method}

USEtox is generally recognized as the most advanced model currently available for comparative assessment of chemicals and their toxic effects on humans and freshwater ecosystems [19]. The paper mainly aimed at the impacts on aquatic ecosystem, therefore the impact score in the model is described as followed:

$$
I S=\sum_{i, j} Q_{i, j} \times C F_{i, j}
$$

where IS is the impact score for ecological toxicity $\left(\mathrm{PAF} \cdot \mathrm{m}^{3} \cdot \mathrm{d}\right), C F_{i, j}$ - the characterisation of substance $i$ released to compartment $j\left(\mathrm{PAF} \cdot \mathrm{m}^{3} \cdot \mathrm{d} / \mathrm{kg}\right)$ and $Q_{i, j}$ the quality of emission $i(\mathrm{~kg})$. The equation has summed over all chemicals and emission compartments in the emissions inventory [8]. The CFs of chemicals are computed as the result of the product of three factors: a fate factor (FF), an exposure factor $(X F)$ and an effect factor (EF). The fate factor represents the residence time of a chemical in a specific compartment, which is directly connected with the degradation capabilities. The effect factor reflects the change in the PAF of species due to change in ecotoxicant concentration and the exposure factor for ecotoxicity is the fraction of a chemical dissolved in a medium.

To calculate the ChF of an emission inventory, equation 2 was put forward by equation 1 . In equation 2 , 290 is dimensionless and is an Correction factor to balance the result of impact scores and ChFs.

$$
C h F=290 \times I S
$$

\section{Calculation boundary}

The first step in accounting chemical footprint is to determine the calculation boundary. The textile production chain is often described as long and complex and includes several production steps, like yarn spinning, weaving, dyeing, sewing and so on. In this paper, the calculation boundary of chemical footprint was from yarn to fabric. Figure 1 briefly shows the industrial production chain of cotton woven fabric in this paper in which processes potentially create more pollution, including weaving and dyeing \& finishing. The weaving was conducted in a weaving factory, while dyeing \& finishing was conducted in a printing and dyeing factory. All the aspects that should be taken into account were both input and output dyes and auxiliaries in these processes. The focus has been on the textile production processes and indirect emissions occurring in the textile life cycle, such as pollutants from fuel combustion and the production of chemicals, were not taken into account.

\section{Data}

In the calculation boundary, chemical species include dyestuffs, bases, sizing agents, desizing agents, stabilizers, bleach, softeners and so on. The main data in the life cycle inventory, like chemical input and output and chemical compositions were provided by two enterprises. The two enterprises that are above designated size have built a relation of upstream and downstream. This article has represented the actual situation of pollution production. Therefore, the data about chemical emissions was all measured before wastewater treatment systems. Characterisation factors were mainly accounted in USEtox model. The left were in Cosmede database and some published literature [20-21]. After the conversion of annual output and consumption data, the functional unit was defined as $1 \mathrm{~kg}$ of cotton woven fabric. The basic information of the fabric is shown in the table 1. 


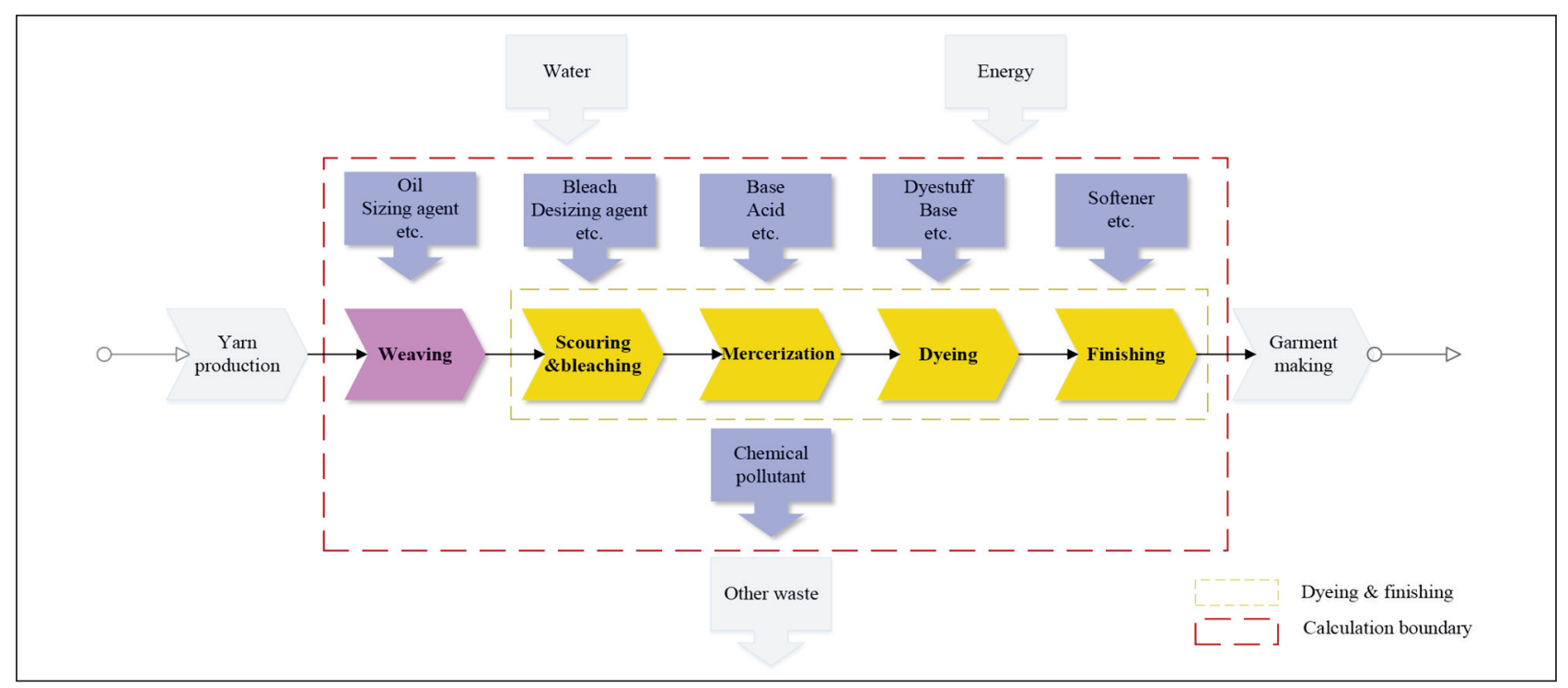

Fig. 1. The calculation boundary of chemical footprint of cotton woven fabric

Table 1

\begin{tabular}{|c|c|}
\hline \multicolumn{2}{|c|}{ FABRIC BASIC INFORMATION } \\
\hline Property & Value \\
\hline Raw material & $100 \%$ cotton \\
\hline Texture & Tabby weaving \\
\hline Weight $\left(\mathrm{g} / \mathrm{m}^{2}\right)$ & 158.5 \\
\hline Warp density $($ yarn $/ \mathrm{cm})$ & 100.4 \\
\hline Weft density $($ yarn $/ \mathrm{cm})$ & 101.6 \\
\hline Thickness $(\mathrm{mm})$ & 0.24 \\
\hline
\end{tabular}

\section{RESULTS AND DISCUSSION}

Figure 2 shows the potential contribution to freshwater ecotoxicity of per $\mathrm{kg}$ cotton woven fabric. According to the results, the total chemical footprint associated with ecotoxicity in the calculation is approximately $41526.10 \mathrm{PAF} \cdot \mathrm{m}^{3} \cdot \mathrm{d}$. The $\mathrm{ChFs}$ of the production processes are obviously different from each other. Weaving process stands for the largest contribution to freshwater ecotoxicity impact and takes more than two thirds of the referred fabric's ChF, then followed by Scouring \& bleaching, Mercerization. Surprisingly, the dyeing process is proved to contribute the least to ecotoxicity and the $\mathrm{ChF}$ was below $10 \mathrm{PAF} \cdot \mathrm{m}^{3} \cdot \mathrm{d}$.

In weaving, yarn especially the warp yarn is required with high strength, on account of subjecting to greater tension. Therefore, before weaving the yarn are sized to lower friction and increase tensile properties during weaving. To improve the sizing performance, the sizing percentage should be limited in a certain range, which means most of the sizing agents will discharge into the environment with waste water [22] and it was the most significant reason why the process contributed a lot to ChF. The one-step pretreatment in wet treatment in this paper is regarded as higher efficient and shorter process. However, due to reduce the impurities of cotton fabrics to low levels, it is necessary to increase the amount of chemical agent, especially for fabrics with high sizing percentage, which increase the burden of wastewater treatment [23]. More eco-friendly chemicals are used in this process, like alpha-amylase, hydrogen peroxide and so on. Mercetization is to improve the luster of cotton woven fabric after alkali treatment. Aimed at lowering the $\mathrm{pH}$ of the fabrics, the residual base on the fabric is neutralized to generate salts. Contrary to expectation, the ChF of dyeing process is not large. It may be assumed that the use and discharge of chemicals are concentrated in the early stage and it costs more time and water to wash in order to achieve the inspection requirements such as $\mathrm{pH}$ value and colour fastness.

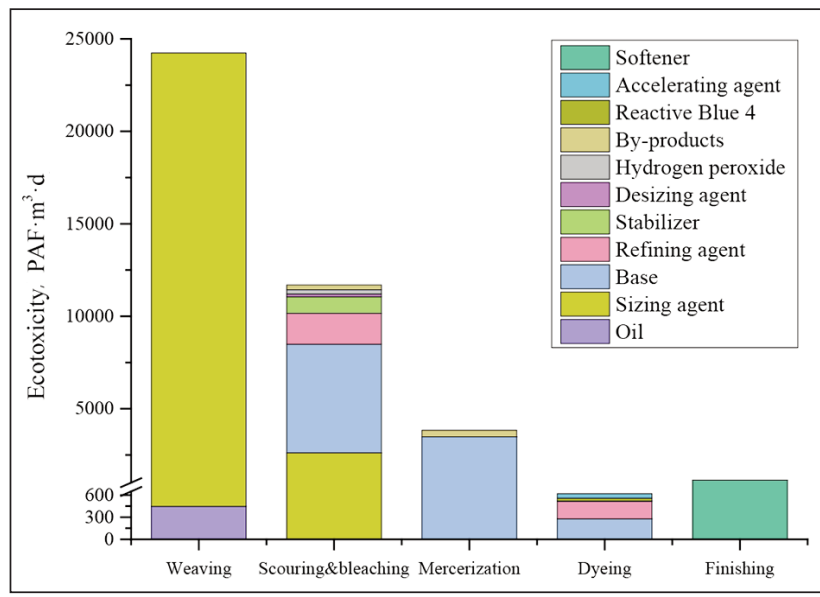

Fig. 2. Comparison of ecotoxicity of process chain segment

Figure 3 shows the process of substances transforming from textile chemicals to chemical pollutants in the calculation boundary. The conversion process of chemical with a larger contribution to the results is represented by a thicker connecting line between the input and output, which we should draw more 
attention to. It is shown that triphenyl phosphate potentially creates the largest ecotoxicity, about 26282.49 $\mathrm{PAF} \cdot \mathrm{m}^{3} \cdot \mathrm{d}$ among all the pollutants, which was generated by sizing agent in the production. Besides, base used in the production also accounts for a large proportion of the total ecotoxicity footprint, nearly $24 \%$. On the other side, pollutants like 1,2propanediol, acetaldehyde and acetaldehyde have little influence on ecotoxicity, with more than 2 orders of magnitude less than other pollutants. Among all the textile chemicals, the sizing agent obviously tends to create a considerable influence on the results.

The size selected in this paper was starch, which had characteristics of cheap price and little pollution to the environment. In order to improve the stiff and brittle performance of starch size film and increase the starch adhesion for cotton, a small amount of plasticizer will be added [24], like triphenyl phosphate in this case. As a persistent organic pollutant, research indicates that a certain dose of triphenyl phosphate has an ecological toxic effect on aquatic organisms [25]. Thus, the CF of this substance is much bigger than others in this paper. Refining agents consist of high-quality environmentally friendly formula, including dodecyl sulfonate, sodium salt lauryl phosphate and primary alcohol ethoxylate. Primary alcohol ethoxylate is the substitute for alkylphenol ethoxylates, which are potential hazardous to environment because of its toxicity and poor biodegradability [26]. The usage of the agent was the largest among all the organic chemicals and a lot of residual agent and the by-products will spew into the water. The impact of the refining agent can by no means be overlooked.
Hydrogen peroxide bleaching agent is proved greener and more environmentally friendly as its degradation products, water and oxygen are harmless [27]. Because darker shades of blue would be added, the amount of bleach is relatively small. But in the scouring \& bleaching, stabilizers are used to control the decomposition rate of hydrogen peroxide. According to the semi-lethal concentration, the stabilizer, silicic acid, sodium is a low-toxic chemical. However, in order to fully improve the utilization rate of hydrogen peroxide, the usage of silicic acid, sodium should be twice as much as that of hydrogen peroxide in beaching. It is the major reason why silicic acid, sodium have great effect on ChF.

In this paper, we focus on the chemical consumption and eco-environmental stress caused by chemical pollution along industrial production chain from yarn to fabric. The weaving process cannot be ignored or underestimated. Large quantity of sizing agent will be directly converted into wastewater if the factory does not carry out recycling. It means that the factory should pay more attention to recycling of size and the recycling equipment. Nowadays, the development of ultrafiltration technology makes it possible for the recovery rate of size to reach $85 \%$ in production. Also, citrate and epoxy vegetable oil plasticizers are kinds of sustainable development of environmental protection plasticizers in industrial production to further reduce the pollution [28]. Minimizing the pollution brought about by sizing agent is highly possible. The process scouring \& bleaching plays an important role in dyeing and finishing. It is claimed that around $45 \%$ quality problems of fabrics are caused by improper pre-treatment [29]. Enzymes tend to be utilized in the

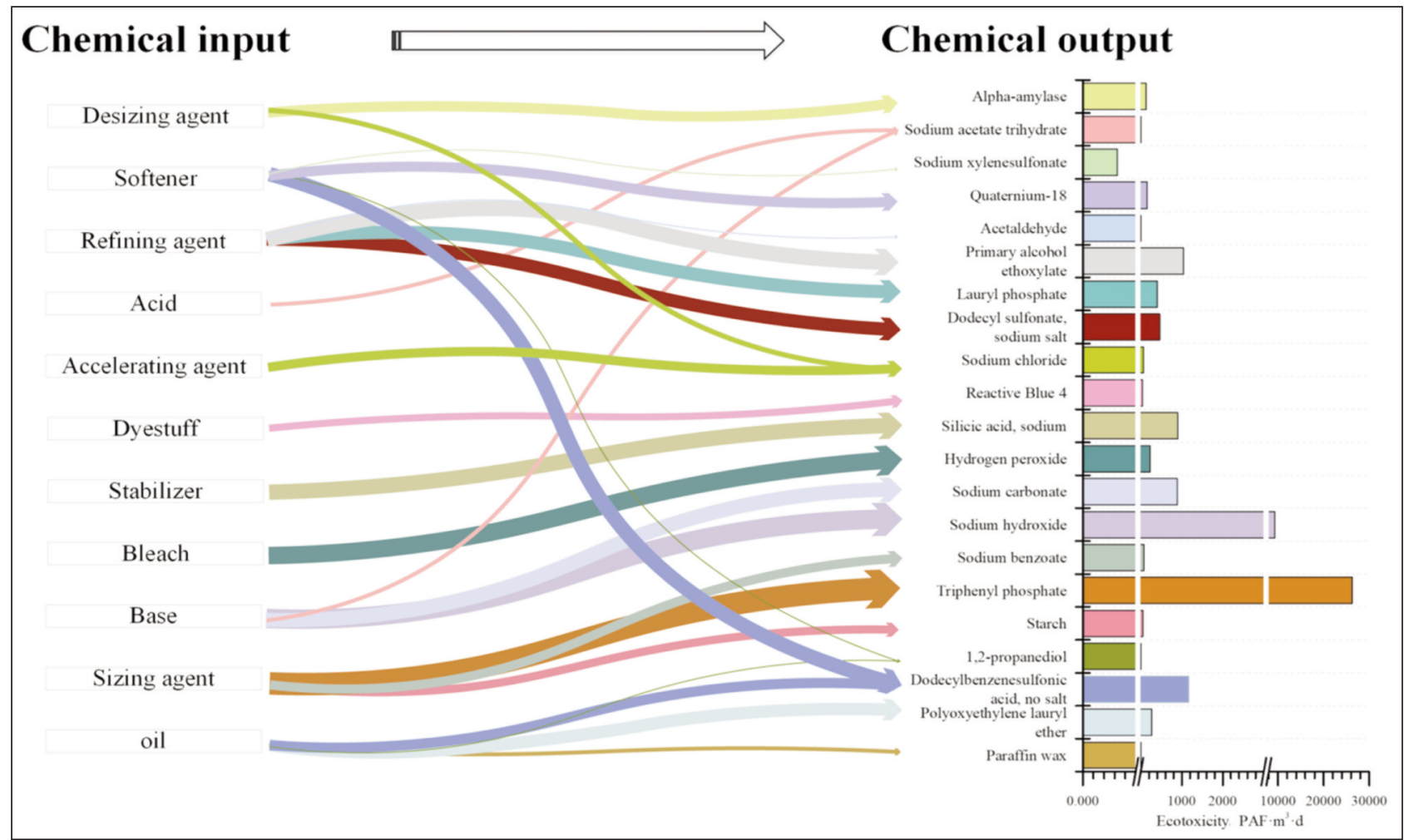

Fig. 3. Sources and ecotoxicity of chemical pollutants 
pre-treatment process of cotton fabrics, which generates minimum by-products and minimizes the risks to humans, wildlife and the environment [30-31]. In mercerizing process, part of the enterprises choose to directly discharge mercerizing wastewater before treating, which results in not only a waste of alkali liquor but also an enormous threat to the environment. Through a reasonable alkali recovery project, dilute alkali can be used in desizing, scouring, mercerizing and other processes [31]. Besides, Liquid ammonia tend to be used as an alternative to sodium hydroxide in mercerization [32-33].

\section{CONCLUSIONS}

The use and emission of toxic chemicals from cotton woven fabric production are an important aspect to include in the impacts on environmental load studies of cotton woven fabrics. In order to mitigate the pollution, wastewater treatment techniques, like physical and chemical techniques, biotechnology and membrane separation technology will be most commonly adopted. However, the treatments just succeed in transferring chemical pollutants to other agents, but essentially fail to put an end to pollution. ChF is a way to help tackle the pollution problems at its source in chemical management.

In this paper, the ecotoxicity of $1 \mathrm{~kg}$ cotton woven fabric was assessed based on ChF methodology. It was shown that the total ecotoxicity was approximately 41526.10 PAF $\cdot \mathrm{m}^{3} \cdot \mathrm{d}$. and weaving was the most typical high toxicity technology. Generally, this might be one of the typical features of cotton woven fabrics. Among all the materials, triphenyl phosphate had the biggest impact on ecotoxicity of ChF due to its persisting pollution and high toxicity to ecosystem. To relieve the environmental load caused by alkaline substances, amylases are recommended in several processes, like desizing. With the prohibiting of high toxicity azo dyestuffs, more environmentally friendly dyestuffs are used as substitutes. Consequently it seems that the selection of auxiliaries is more important than the selection of dyestuffs, which is contrary to the common view that heavy focus should be put on how to choose dyestuffs.

As a quantitative assessment tool, ChF allows for identification of the technologies, pollution sources and pollutants, which can help companies recognize and prioritize opportunities for improvement to save cost and materials. Besides, ChF methodology also provides a new way of thinking for the development of future industrial emission standards in a more reasonable way of considering the toxic effects of pollutants.

Currently, there are still many challenges to overcome when it comes to the sustainable use of chemicals in the textile industry. The secret formula is one of them and it means more requirements will be set to chemical manufacturers. In future research, efforts are needed to be done to enrich the database and develop a model in order to make the evaluation process more systematized and efficient.

\section{ACKNOWLEDGMENTS}

The paper was supported by the National Key R\&D Program Subsidized Projects (2018YFF0215703), Zhejiang Provincial Natural Science Foundation of China (LY20G030001), the Young Researchers Foundation of Zhejiang Provincial Key Laboratory of Fiber Materials and Production Technology, Zhejiang Sci-Tech University (Project No. 2016QN06) and the Natural Science Foundation of China (Grant No. 61702460). The authors are also thankful to Sandra Roos, the researcher of Swerea IVF, for the guidance about how to select the CF of a specific substance.

\section{REFERENCES}

[1] Tian, Z., Wang, L., Li, Y., Calculation and assessment of chemical footprint of textiles and apparel, In: Silk, 2018, 56, 1, 33-37

[2] Barbi, F., Ferreira, L.C., Guo, S., Climate change challenges and China's response: mitigation and governance, In: Journal of Chinese Governance, 2016, 1, 2, 324-339

[3] Ortiz de García, S., García-Encina, P.A., Irusta-Mata, R., The potential ecotoxicological impact of pharmaceutical and personal care products on humans and freshwater, based on USEtoxTM characterization factors. a Spanish case study of toxicity impact scores, In: Science of the Total Environment, 2017, 609, 429-445

[4] Tan, Y., Fang, K., Environmental governance in China, In: Journal of Chinese Governance, 2016, 1, 1, 191-194

[5] Du, C., Wang, Z., Chen, J., Qian, X., Li, X., Xie, H., Cai, X., Chemical Footprint: Concepts, Research Progress and Challenges, In: Asian Journal of Ecotoxicolog, 2018, 11, 2, 18-26

[6] Rosenbaum, R.K., Huijbregts, M.J.A., Henderson, A.D., Margni, M., McKone, T.E., Meent, D., Hauschild, M.Z., Shaked, S., Li, D.S., Gold, L.S., Jolliet, O., USEtox human exposure and toxicity factors for comparative assessment of toxic emissions in life cycle analysis: sensitivity to key chemical properties, In: The International Journal of Life Cycle Assessment, 2011, 16, 8, 710-727

[7] Sala, S., Goralczyk, M., Chemical footprint: A methodological framework for bridging life cycle assessment and planetary boundaries for chemical pollution, In: Integrated Environmental Assessment and Management, 2013, 9, 4, 623-632

[8] Bjørn, A., Diamond, M., Birkved, M., Hauschild, M.Z., Chemical footprint method for improved communication of freshwater ecotoxicity impacts in the context of ecological limits, In: Environmental Science \& Technology, 2014, 48, 22, 13253-13262

[9] Roos, S., Posner, S., Jönsson, G., Peters, G.M., Is Unbleached Cotton Better Than Bleached? Exploring the Limits of Life-Cycle Assessment in the Textile Sector, In: Clothing and Textiles Research Journal, 2015, 33, 4, 231-247

[10] Wang, Y., Global fiber production: Slowdown of growth to only 1.7\%, In: Melliand China, 2018, 46, 3, 4-12 
[11] Hasanbeigi, A., Price, L., A technical review of emerging technologies for energy and water efficiency and pollution reduction in the textile industry, In: Journal of Cleaner Production, 2015, 95, 30-44

[12] Hellweg, S., Milà i Canals, L., Emerging approaches, challenges and opportunities in life cycle assessment, In: Science, 2014, 344, 6188, 1109

[13] Muthu, S.S., Yi, L., Hu, J., Mok, P., Lin, M., Modelling and quantification of Eco-functional Index: The concept and applications of eco-functional assessment, In: Ecological Indicators, 2013, 26, 33-43

[14] Gondran, N., The ecological footprint as a follow-up tool for an administration: Application for the Vanoise National Park, In: Ecological Indicators, 2012, 16, 157-166

[15] Wang, L., Wu, X., Ding, X., Wang, L., Yu, J., Case study on industrial carbon footprint and industrial water footprint of cotton knits, In: China Dyeing \& Finishing, 2012, 38, 2, 43-46

[16] Yan, Y., Jia, J., Wang, L., Du, C., Liu, X., Fu, X., Liu, X., Wu, G., The industrial water footprint of several typical cotton textiles in China, In: Acta Ecologica Sinica, 2014, 34, 23, 7119-7126

[17] Li, X., Xu, W., Zhu, J., Yang, Y., Calculation method of cotton carded yarn carbon footprint, In: Cotton Textile Technology, 2014, 42, 9, 19-23

[18] Wang, Z., Chen, J., Zhang, L., Chen, F., Sun, H., Liu, L., Song, W., Li, C., Li, Y., Carbon footprint analysis of cotton production in Hebei Province, In: Journal of Cotton Science, 2016, 28, 6, 594-600

[19] Hauschild, M.Z., Huijbregts, M., Jolliet, O., Macleod, M., Margni, M., van De Meent, D., Rosenbaum, R.K., Mckone, T.E., Building a model based on scientific consensus for life cycle impact assessment of chemicals: the search for harmony and parsimony, In: Environmental Science \& Technology, 2008, 42, 7032-7037

[20] Roos, S., Holmquist, H., Jönsson, C., Arvidsson, R., USEtox characterisation factors for textile chemicals based on a transparent data source selection strategy, In: The International Journal of Life Cycle Assessment, 2018, 23, 4, 890-903

[21] Roos, S., Peter, G.M., Three methods for strategic product toxicity assessment - the case of the cotton T-shirt, In: The International Journal of Life Cycle Assessment, 2013, 20, 7, 903-912

[22] Guo, Q., Cui, X., Control Measures of Stabilizing Sizing Percentage, In: Cotton Textile Technology, 2017, 45, 7, 60-63

[23] Wu, J., High Efficient and Short Process of Pre-treatment Process of Cotton and T/C Fabric, In: China Textile Leader, 2016, 4, 36-39

[24] Zhou, D., Shen, Y., Qian, X., Influence of plasticizer on starch size performance, In: Progress in Textile Science \& Technology, 2012, 1, 17-18, 92

[25] Luo, Y., Liu, N., Xu, J., Hu, X., Xu, Y., Jin, X., A tiered ecological risk assessment of triphenyl phosphate in Chinese surface waters, In: Asian Journal of Ecotoxicolog, 2018, 13, 5, 87-96

[26] Chen, R., Prohibition and substitution of APEO, In: China Dyeing \& Finishing, 2016, 32, 12, 45-49

[27] Sujata, S., Raja, A.S.M., Arputharaj, A., Challenges in Sustainable Wet Processing of Textiles. Textiles and Clothing Sustainability, Springer Singapore, 2017, 46-47

[28] Chen, R., Development of phthalate and environmental friendly plasticizer substitute, In: Textile Auxiliaries, 2011, $28,12,1-8$

[29] Liu, J., New energy conservation and emission reduction technologies in dyeing and finishing, In: China textile \& apparel press, Beijing, 2015, 10-12

[30] Choudhury, AK.R., Sustainable textile wet processing: applications of enzymes. Roadmap to Sustainable Textiles and Clothing, Springer Singapore, 2014, 1-36

[31] Buschle-Diller, G., Yang, X.D., Yamamoto, R., Enzymatic bleaching of cotton fabric with glucose oxidase, In: Textile Research Journal, 2001, 71, 5, 388-394

[32] Wang, J., Yu, C., Jiang, S., Yu, W., Application of recycling of dilute alkali from mercerizing, In: Textile Dyeing and Finishing Journal, 2013, 35, 1, 47-50

[33] Arputharaj, A., Raja, A.S.M., Saxena, S., Developments in Sustainable Chemical Processing of Textiles. Green Fashion, Springer Singapore, 2016, 224

Authors:

JIA-HONG QIAN ${ }^{1,3}$, YU-YING QIU ${ }^{2}$, YI-DUO YANG ${ }^{1,3}$, YI LI $^{4}$, PING-HUA XU1 ${ }^{1,3}$, LAI-LI WANG 1,3,4

1Zhejiang Provincial Research Center of Clothing Engineering Technology, Hangzhou, 310018, Zhejiang, China

${ }^{2}$ College of Design, Jiaxing University, Jiaxing, 314001, Zhejiang, China

${ }^{3}$ Silk and Fashion Culture Research Center of Zhejiang Province, Sci-Tech University, Hangzhou, 310018, Zhejiang, China

${ }^{4}$ Zhejiang Ecological Civilization Research Center, Hangzhou, 310018, Zhejiang, China e-mail: 201720401008@mails.zstu.edu.cn; skyqyy@163.com; 2017328420054@mails.zstu.edu.cn; liyi2009@zstu.edu.cn; shutexph@163.com

\section{Corresponding author:}

LAI-LI WANG

e-mail: wangll@zstu.edu.cn 